\title{
Effects of Hybrid Polypropylene-Steel Fiber Addition on Some Hardened Properties of Lightweight Concrete with Pumice Breccia Aggregate
}

\author{
Slamet Widodo, ${ }^{1}$ Iman Satyarno, ${ }^{2}$ and Sri Tudjono ${ }^{1}$ \\ ${ }^{1}$ Civil Engineering Department, Diponegoro University, Semarang 50241, Indonesia \\ ${ }^{2}$ Civil and Environmental Engineering Department, Gadjah Mada University, Yogyakarta 55281, Indonesia \\ Correspondence should be addressed to Slamet Widodo, swidodo@outlook.com
}

Received 4 November 2012; Accepted 28 November 2012

Academic Editors: M. Maslehuddin and A. A. Torres-Acosta

Copyright ( $) 2012$ Slamet Widodo et al. This is an open access article distributed under the Creative Commons Attribution License, which permits unrestricted use, distribution, and reproduction in any medium, provided the original work is properly cited.

\begin{abstract}
Lightweight concrete application in construction field is growing rapidly in these recent years due to its advantages over ordinary concrete. In this paper, pumice breccia which can be found abundantly in Indonesia is proposed to be utilized as the coarse aggregate. In spite of its benefits, lightweight concrete exhibits more brittle characteristics and lower tensile strength compared with normal concrete. On the other hand, fiber addition into concrete has become widely used to improve its tensile properties. Furthermore, the utilization of hybrid fiber in a suitable combination may potentially improve the mechanical properties of concrete. This paper experimentally examines the effects of hybrid polypropylene-steel fiber addition on some hardened properties of pumice breccia aggregate lightweight concrete. Five groups of test specimens with fixed volume fraction of polypropylene fiber combined with different amounts of steel fiber were added in concrete to investigate the density, compressive strength, modulus of elasticity, splitting tensile strength, and the modulus of rupture of the concrete mixtures. Test results indicate that hybrid fiber addition leads to significant improvement to the compressive strength, modulus of elasticity, splitting tensile strength, and the modulus of rupture of the pumice breccia lightweight aggregate concrete and meet the specification for structural purposes.
\end{abstract}

\section{Introduction}

1.1. Background. Lightweight concrete (LWC) application in construction field is growing rapidly in these recent years both for structural and nonstructural purposes due to its advantages over ordinary concrete. The demand for lightweight concrete in many applications of modern construction is increasing, owing to the advantage that lower density results in a significant benefit in terms of load bearing elements of smaller cross sections and a corresponding reduction in the size of the foundation. The maximum density of concrete which can be classified as lightweight concrete in some European construction codes is limited to $2000 \mathrm{~kg} / \mathrm{m}^{3}$ [1], while the limitation in Indonesian National Standard is $1900 \mathrm{~kg} / \mathrm{m}^{3}$ [2], compared with that of $2400 \mathrm{~kg} / \mathrm{m}^{3}$ for normal weight concrete (NWC). Some techniques that are widely used for lightweight concrete development include utilization of natural lightweight aggregates such as pumice, diatomite, and volcanic cinders, or artificial byproducts such as perlite, expanded shale, clay, slate, and sintered pulverized fuel ash (PFA). Lightweight aggregate can be defined as mixture of uncrushed and/or crushed grains for natural and/or manufactured minerals which in most of the national codes required a limitation of the particle density not exceeding $2000 \mathrm{~kg} / \mathrm{m}^{3}$ or a dryloose bulk density not exceeding $1200 \mathrm{~kg} / \mathrm{m}^{3}$ [1-5]. In this research, pumice breccia which can be found abundantly in Indonesia is proposed to be utilized as the coarse aggregate in the mixtures.

In spite of its benefits, lightweight concrete exhibits its brittle characteristics and lower tensile strength compared with normal concrete. On the other hand, fiber addition into concrete mixes becomes more widely used to improve concrete tensile behavior. The geometrical size and modulus 
of elasticity of fibers are the main factors which will affect the performances of fiber reinforced concrete. In order to optimize the benefits of fiber addition in concrete construction, the application of different fiber types into fresh concrete mixtures was introduced and commonly known as hybrid fiber reinforced concrete (HyFRC). It becomes more popular in these recent years and expected to provide better physical and mechanical properties in concrete for structural purposes. The use of different types of fiber in a suitable combination may potentially improve the mechanical properties of concrete and result in synergic performance [6-9]. Addition of steel fiber generally provides contribution to the energy absorbing mechanism (bridging action), while nonmetallic fibers offer its ability to delay the formation of microcracks and avoid catastrophic breaking, and also has much lower density [9].

1.2. Objectives. The main objectives of this research include (1) developing hybrid fiber reinforced lightweight concrete mixtures which should be suitable for structural applications using locally available materials, (2) examining the properties of the developed fiber reinforced lightweight concrete mixes, including demoulded density, compressive strength, modulus of elasticity, splitting tensile strength, and the modulus of rupture, and (3) studying the flexural load-displacement behavior of the lightweight concrete with hybrid fiber addition.

\section{Experimental Work}

2.1. Materials and Mix Proportion. In this research, polypropylene fiber (PPF) and steel fiber (SF) were chosen to be utilized as hybrid fiber. Polypropylene was used due to being inexpensive, inert in high $\mathrm{pH}$ cementitious environment, and easy to disperse. In this research, monofilament polypropylene with $18 \mu \mathrm{m}$ diameter, $12 \mathrm{~mm}$ length, and $0.91 \mathrm{~g} / \mathrm{cm}^{3}$ density was used. Steel fiber was chosen as the macrofiber based in its proven ability on the energy absorbing mechanism (bridging action), and its easiness to be found. The steel fiber that is applied in this research is hooked-end steel fiber having $60 \mathrm{~mm}$ length, and $0.75 \mathrm{~mm}$ of diameter.

The mixtures were prepared with blended cement containing $23.13 \%$ of $\mathrm{SiO}_{2}, 8.76 \%$ of $\mathrm{Al}_{2} \mathrm{O}_{3}, 4.62 \%$ of $\mathrm{Fe}_{2} \mathrm{O}_{3}$, $58.66 \%$ of $\mathrm{CaO}, 0.90 \%$ of $\mathrm{MgO}, 2.18 \%$ of $\mathrm{SO}_{3}$, and $1.69 \%$ of loss on ignition which satisfies the requirements in the Indonesian Standards for Pozzolan Portland Cement [10]. The coarse aggregate was prepared using continuously graded crushed lightweight pumice breccia from Bawuran Mountain, Bantul District in the Special Province of Yogyakarta which is one of the largest pumice breccia deposits in Indonesia. This pumice breccia has dry-loose bulk density of $760 \mathrm{~kg} / \mathrm{m}^{3}$ with particle density of $1620 \mathrm{~kg} / \mathrm{m}^{3}$ which satisfies to the technical specification of lightweight aggregate. Therefore, it is proposed to be utilized as coarse aggregate in the mixtures. The coarse aggregates with maximum size of $20 \mathrm{~mm}$ were prewetted and submerged in water in 24 hours and then air-dried to be in saturated surface
TABle 1: Mixture proportion.

\begin{tabular}{lccccc}
\hline \multirow{2}{*}{ Material } & \multicolumn{5}{c}{ Mix type } \\
& A & B & C & D & E \\
\hline Water $\left(\mathrm{lt} / \mathrm{m}^{3}\right)$ & 225.00 & 225.00 & 225.00 & 225.00 & 225.00 \\
Portland cement $\left(\mathrm{kg} / \mathrm{m}^{3}\right)$ & 455.00 & 455.00 & 455.00 & 455.00 & 455.00 \\
Silica fume $\left(\mathrm{kg} / \mathrm{m}^{3}\right)$ & 45.00 & 45.00 & 45.00 & 45.00 & 45.00 \\
Coarse aggregate $\left(\mathrm{kg} / \mathrm{m}^{3}\right)$ & 606.81 & 606.81 & 606.81 & 606.81 & 606.81 \\
Sand $\left(\mathrm{kg} / \mathrm{m}^{3}\right)$ & 538.52 & 538.52 & 538.52 & 538.52 & 538.52 \\
Superplasticizer $\left(\mathrm{lt} / \mathrm{m}^{3}\right)$ & 4.70 & 4.70 & 4.70 & 4.70 & 4.70 \\
Set retarder $\left(\mathrm{lt} / \mathrm{m}^{3}\right)$ & 0.70 & 0.70 & 0.70 & 0.70 & 0.70 \\
Polypropylene $\left(\mathrm{kg} / \mathrm{m}^{3}\right)$ & 0.90 & 0.90 & 0.90 & 0.90 & 0.90 \\
Steel fiber $\left(\mathrm{kg} / \mathrm{m}^{3}\right)$ & 0.00 & 33.50 & 67.00 & 100.50 & 134.00 \\
\hline
\end{tabular}

dry condition before mixing process. Well-graded natural sand with specific gravity of 2.65 was employed as the fine aggregate. Silica fume, naphthalene formaldehyde sulfonatbased superplasticizer, and set retarder were also utilized as concrete admixtures in this research. Fiber addition was applied using fixed $0.10 \%$ volume fraction of PPF, and various $\mathrm{SF}$ addition of $0.0 \%, 0.5 \%, 1.0 \%, 1.5 \%$, and $2.0 \%$ by volume into the mixtures. Detail of mixes proportion can be found in Table 1 .

All those concrete variants will be evaluated and analyzed further, based on the reference LWC mixture which was added with $0.10 \%$ PPF and $0.0 \%$ SF. This reference mixture was chosen due to the fact that extensive use has been made in the construction industry for the application of short $(<25 \mathrm{~mm}$ long) fibrillated or monofilament PPF to alter the properties of the fresh concrete, notably to reduce the extent of plastic shrinkage cracking should it occur. These fibers are typically $12 \mathrm{~mm}$ long by $18 \mu \mathrm{m}$ diameter which is commonly added at a recommended dosage of approximately $0.90 \mathrm{~kg} / \mathrm{m}^{3}$ that is equal to 0.1 percent by volume of concrete. For the system containing 0.1 per cent by volume of PPF, it can easily be shown a theoretical analysis that the fibers will have little measurable effect on the tensile or flexural strength of hardened concrete and that they cannot be considered as a primary reinforcement [11].

In accordance with the above-mentioned theoretical prediction, the effect of PPF has been researched in respect of the properties of LWAC. In most cases, it was reported that PPF has no effect on the compressive strength of LWAC. The addition of PP fibers in volume fractions lower than $1 \%$ does not significantly increase the splitting tensile strength of sanded LWAC and does not significantly affect the flexural strength and toughness. They demonstrated that this might be due to the lower tensile strength of PP fiber and also the weaker bond between PP fibers and the cement matrix [12]. Similar with those experimental results, some researchers reported that the addition of PPF also did not significantly affect the compressive strength and modulus elasticity of EPS concrete [13].

2.2. Details of Experimental Tests. Fresh characteristics of concrete mixes were evaluated using slump test method based on ASTM C-143 [14]. In order to observe the density 
TABLE 2: Effects of hybrid polypropylene-steel fiber addition on hardened properties of LWC with pumice breccia aggregate (mean \pm standard deviation).

\begin{tabular}{lccccc}
\hline $\begin{array}{l}\text { Volume fraction of } \\
\text { steel fiber } \\
(\%)\end{array}$ & $\begin{array}{c}\text { Demoulded density } \\
\left(\mathrm{kg} / \mathrm{m}^{3}\right)\end{array}$ & $\begin{array}{c}\text { Compressive strength } \\
(\mathrm{MPa})\end{array}$ & $\begin{array}{c}\text { Modulus of elasticity } \\
(\mathrm{MPa})\end{array}$ & $\begin{array}{c}\text { Splitting tensile strength } \\
(\mathrm{MPa})\end{array}$ & $\begin{array}{c}\text { Modulus of rupture } \\
(\mathrm{MPa})\end{array}$ \\
\hline 0.0 & $1764.78 \pm 5.92$ & $16.45 \pm 0.35$ & $7317.49 \pm 396.18$ & $1.24 \pm 0.07$ & $2.78 \pm 0.16$ \\
0.5 & $1857.33 \pm 16.18$ & $19.15 \pm 0.43$ & $9125.91 \pm 353.25$ & $2.56 \pm 0.12$ & $4.45 \pm 0.22$ \\
1.0 & $1874.06 \pm 10.45$ & $20.14 \pm 0.54$ & $8191.96 \pm 409.67$ & $3.06 \pm 0.03$ & $7.16 \pm 0.36$ \\
1.5 & $1902.09 \pm 17.53$ & $19.71 \pm 0.64$ & $7492.72 \pm 657.91$ & $3.99 \pm 0.23$ & $8.00 \pm 0.73$ \\
2.0 & $1932.86 \pm 3.74$ & $18.56 \pm 0.41$ & $6836.53 \pm 872.73$ & $3.76 \pm 0.18$ & $7.98 \pm 0.72$ \\
\hline
\end{tabular}

on demoulding as declared in BS EN 8500:1 2006 [15], specimens' weight and dimensions were measured 24 hours after concrete casting. The compressive strength, modulus of elasticity, splitting tensile strength, and the modulus of rupture were evaluated after the hardened concrete specimens were cured with 56 days water immersion since all the mixtures were added with silica fume as mineral admixture. Compressive strength and modulus of elasticity evaluation for all the variants of concrete was done on cylinders of $150 \mathrm{~mm}$ in diameter and $300 \mathrm{~mm}$ length, based on ASTM C469 [14]. The compressive strength and modulus of elasticity of the concrete were determined as the average of those three specimens for each variant. The splitting tensile strength of concrete was taken as the average result of the three cylinders with $150 \mathrm{~mm}$ in diameter and $300 \mathrm{~mm}$ length for each variant, which were tested using Brazilian splitting tensile test based on ASTM C-496 [14]. Modulus of rupture test was conducted on simply supported beam with center-point loading following the procedure in ASTM C-293 [14]. The test was carried out on the beams with $100 \mathrm{~mm} \times 100 \mathrm{~mm}$ of cross-sectional dimension and $500 \mathrm{~mm}$ length, and the modulus of rupture was taken as the average of those three beams for each variant.

\section{Results and Discussion}

In this research, the effect of steel fiber addition on the workability of polypropylene fiber-reinforced lightweight concrete was evaluated using slump-test method based on ASTM C-143 [14]. Comparison of the measured slump of the fresh fiber-reinforced lightweight concrete mixtures can be found in Figure 1. Based on the following graph, it can be observed that the addition of steel fiber into the concrete tends to decrease the workability of the hybrid fiber reinforced lightweight concrete (HyFRLWC) mixtures.

In order to evaluate the effects of hybrid polypropylene and steel fiber addition on hardened properties of LWC with pumice breccia aggregate, the compressive strength, modulus of elasticity, splitting tensile strength, and the modulus of rupture of the concrete specimens were tested after 56 days of water immersion to achieve more representative results of concrete strength since all the mixtures were added with silica fume. Table 2 shows the results of the tests.

Effects of fiber content on demoulded density of hardened lightweight pumice breccia aggregate concrete can

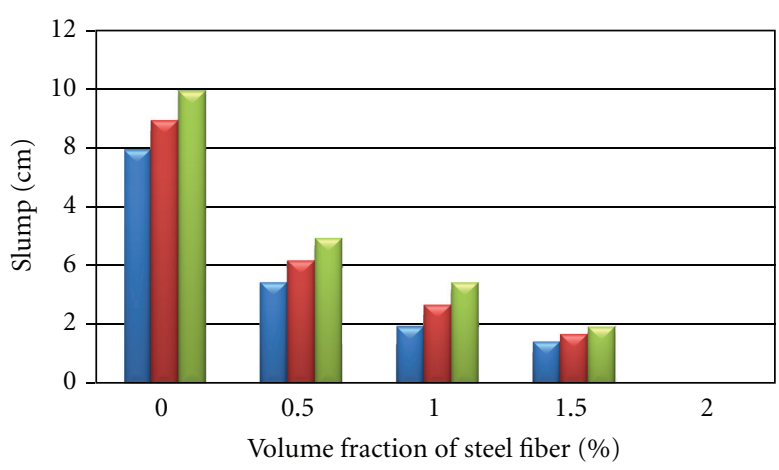

$$
\begin{aligned}
& \text { Min. } \\
& \text { Average } \\
& \text { Max. }
\end{aligned}
$$

FIgURE 1: Effect of steel fiber addition on the workability of HyFRLWC with pumice breccia aggregate added with $0.1 \%$ PPF and various volume fractions of SF.

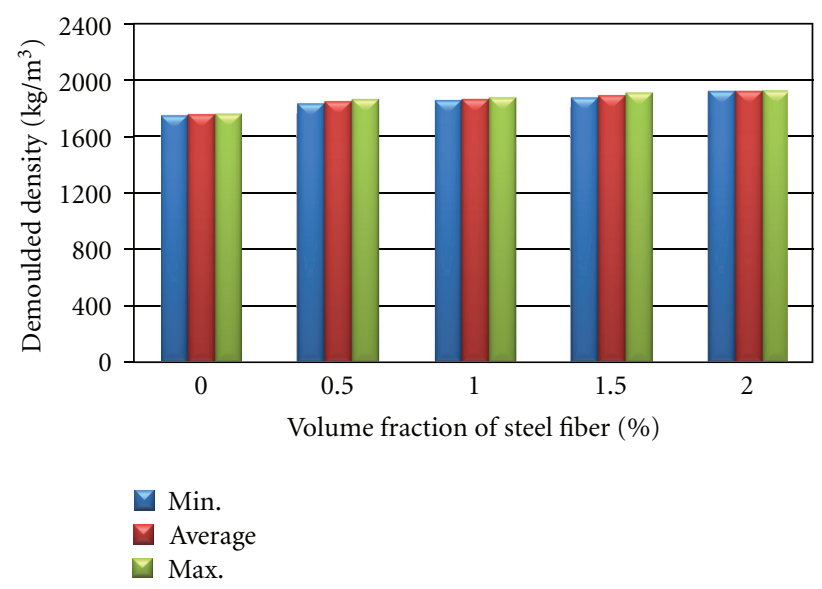

FIGURE 2: Effect of steel fiber addition on the demoulded density of HyFRLWC with $0.1 \%$ PPF and various volume fractions of SF.

be observed in Figure 2. The demoulded density tends to increase in accordance with the addition of steel fiber into the mixes. It can be clearly predicted in the mix design calculation since steel fiber has much higher density compared to the lightweight pumice breccia concrete. 


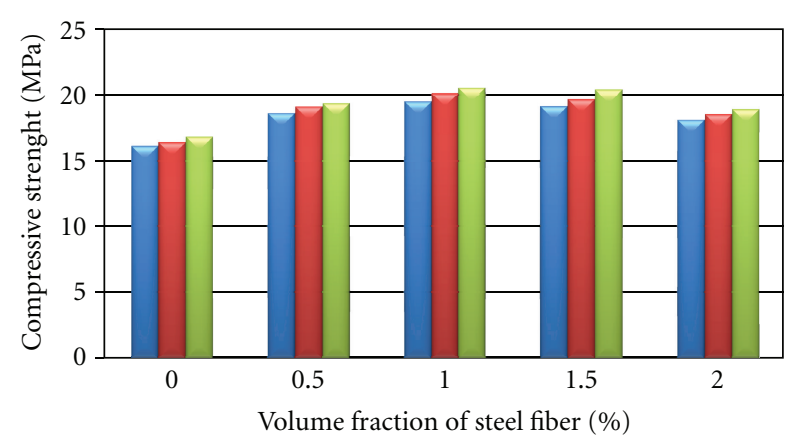

$$
\begin{aligned}
& \square \text { Min. } \\
& \square \text { Average } \\
& \square \text { Max. }
\end{aligned}
$$

FIGURE 3: Effect of steel fiber addition on the compressive strength of HyFRLWC with $0.1 \%$ PPF and various volume fractions of SF.

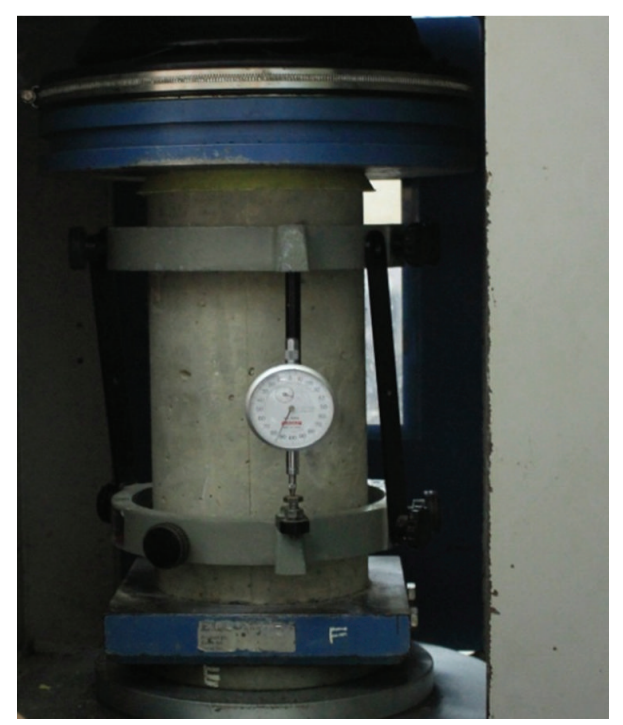

FIGURE 4: Compressive strength and modulus of elasticity test setup.

Even though the demoulded density of HyFRLWC with pumice breccia aggregate increases due to the presence of steel fiber, it can be observed that the density of the lightweight concretes with hybrid polypropylene and steel fiber addition up to the combination of $0.1 \%$ PPF and $1.5 \%$ SF is still acceptable to be classified as lightweight concrete based on the maximum limit of lightweight concrete density which is required in the Indonesian national standard and most of the international standards.

Compressive strength evaluation of hardened HyFRLWC with pumice breccia aggregate can be found in Figure 3. Test results indicate that the compressive strength tends to increase up to $22.44 \%$ when the fibers added with the combination of $0.1 \% \mathrm{PPF}$ and $1.0 \% \mathrm{SF}$ and then tends to decrease after the optimum volume fraction but still shows higher compressive strength compared to the reference mixture.

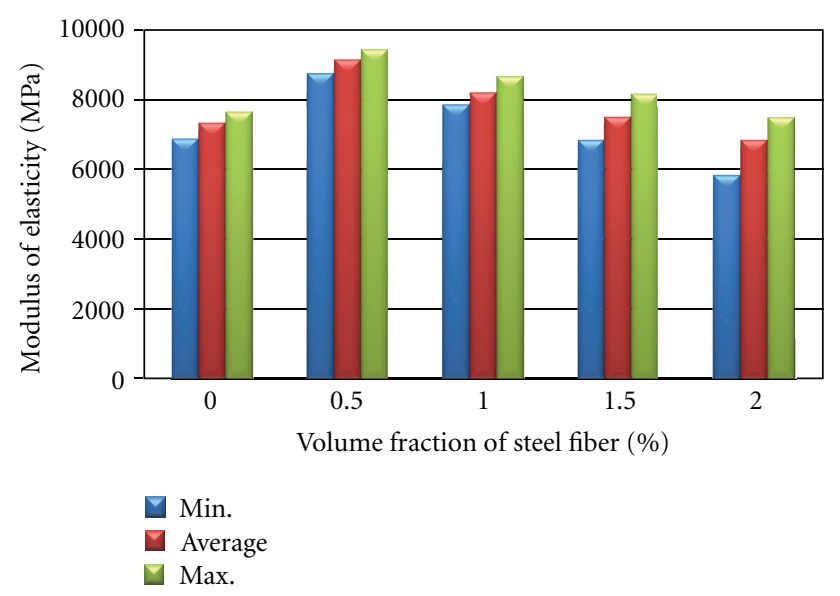

FIGURE 5: Effect of steel fiber addition on the modulus of elasticity of HyFRLWC with $0.1 \%$ PPF and various volume fractions of SF.

Modulus of elasticity of the hardened HyFRLWC with pumice breccia aggregate was also investigated at the same time with compression test as shown in Figure 4. The modulus of elasticity tends to increase up to $24.71 \%$ when the fibers are added with the combination of $0.1 \% \mathrm{PPF}$ and $0.5 \%$ SF but then tends to decrease. Even though the modulus of elasticity tends to decrease after the optimum value of fiber hybridization, the HyFRLWC with pumice breccia aggregate still achieves higher modulus of elasticity compared to the reference concrete unless for mixed $0.1 \%$ PPF and 2.0\% SF as shown in Figure 5.

In order to get more comprehensive results, the curves that show stress-strain relationship in concrete compression tests are also shown in Figure 6. Based on the stress-strain curves, it can be observed that HyFRLWC with pumice breccia aggregate showing better post-peak behavior in resisting applied compression force compared to the reference concrete. HyFRLWC variants exhibit higher residual strength and better strain capacity. This can be observed due to the effect of steel fiber on the energy absorbing mechanism by bridging action to distribute macrocracks that are caused by applied external force, while polypropylene fiber shows its contribution to delay the formation of microcracks, improve the pull-out strength of steel fiber, and avoid catastrophic breaking. Furthermore, it can be concluded that the addition of hybrid polypropylene-steel fiber into lightweight pumice breccia aggregate concrete mixes shows its contribution to improve the post-peak behavior and avoid sudden failure in concrete compression test. The concrete behavior when resisting compressive load can be observed based on the stress-strain graphs as shown in Figure 6.

Test results which are related to the effects of hybrid fiber addition on the splitting tensile strength of hardened lightweight pumice breccia aggregate concrete can be observed in Figure 7. Hybrid fiber addition significantly improves the splitting tensile strength up to $222.28 \%$ when the concrete mix is added with the combination of $0.1 \%$ PPF and $1.5 \%$ SF. After the optimum volume fraction of hybrid fiber addition, the splitting tensile strength tends to decrease 


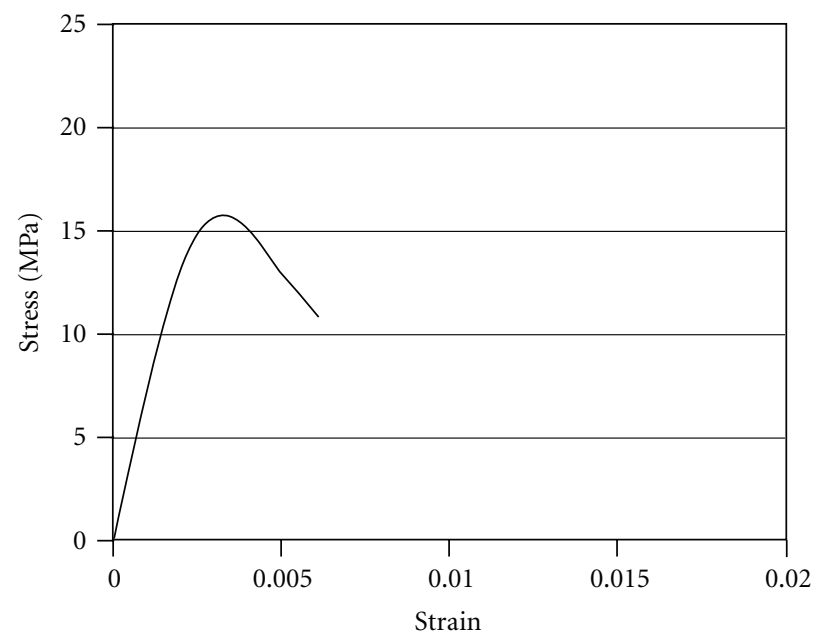

(a)

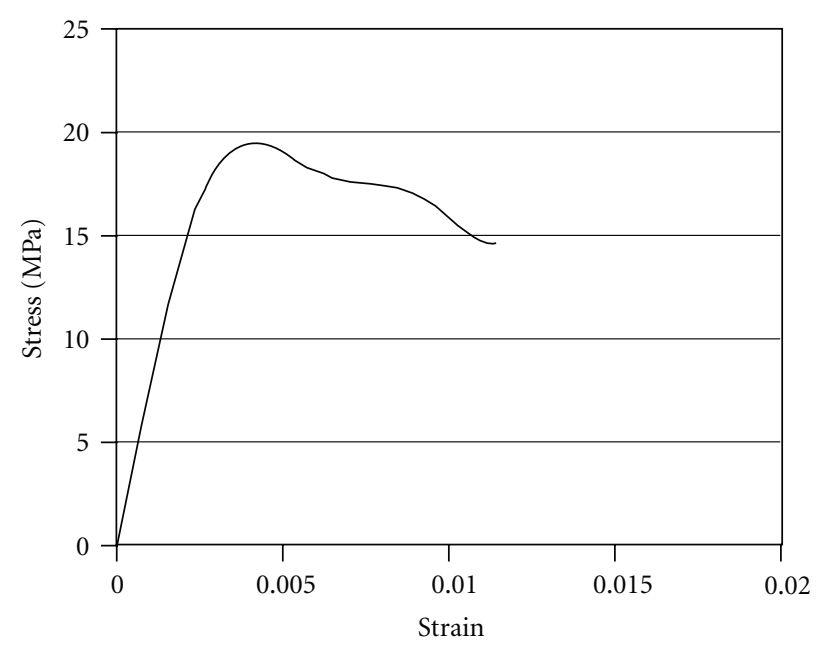

(c)

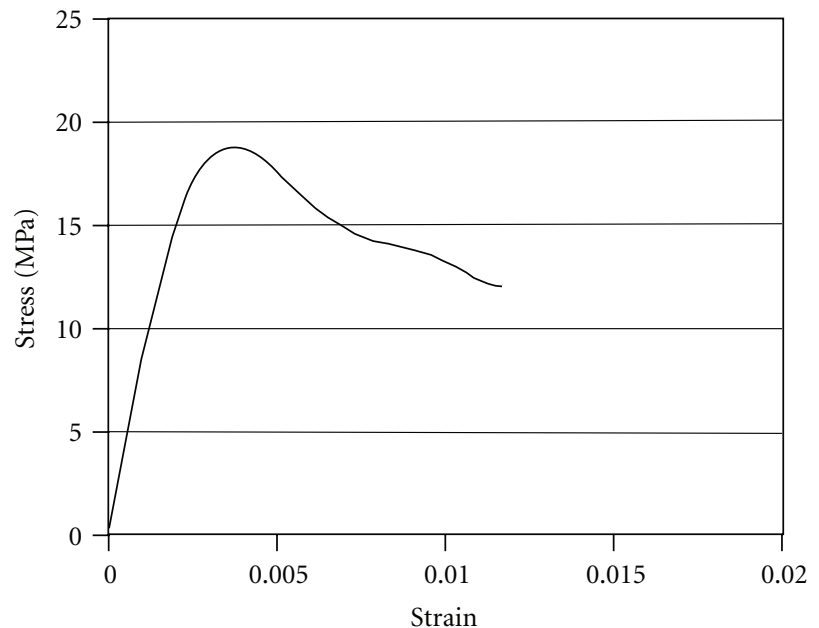

(b)

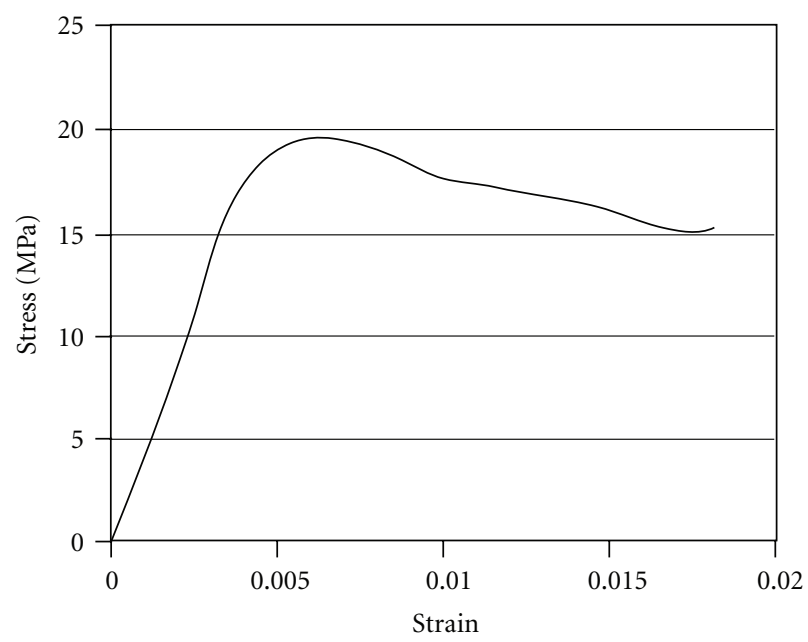

(d)

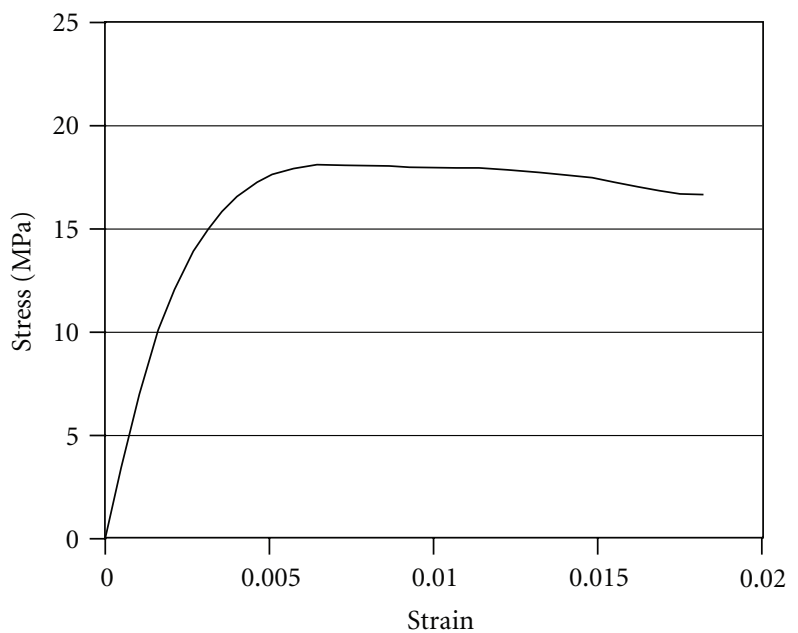

(e)

Figure 6: Stress-strain behavior in compression tests of HyFRLWC with pumice breccia aggregate added with $0.1 \%$ PPF and (a) $0.0 \%$ SF, (b) $0.5 \% \mathrm{SF}$, (c) $1.0 \% \mathrm{SF}$, (d) $1.5 \% \mathrm{SF}$, and (e) $2.0 \% \mathrm{SF}$. 


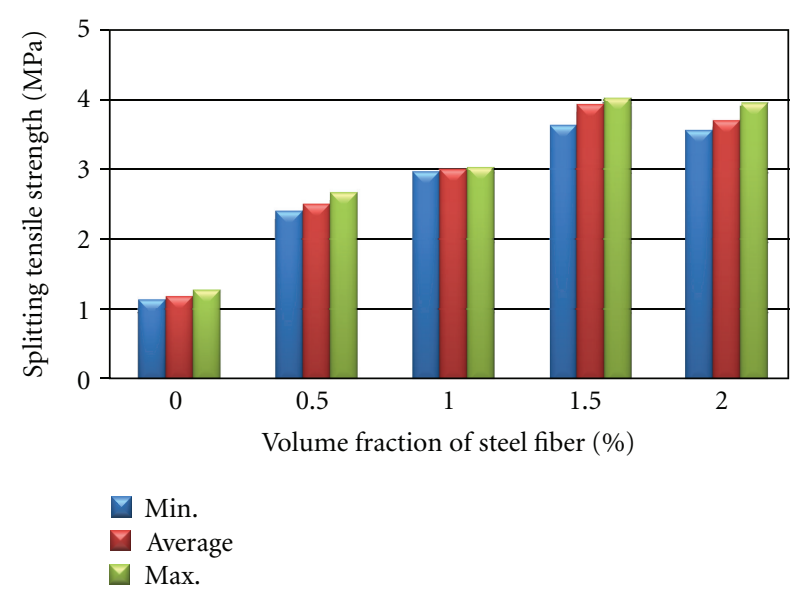

Figure 7: Effect of steel fiber addition on the splitting tensile strength of HyFRLWC with $0.1 \%$ PPF and various volume fractions of SF.

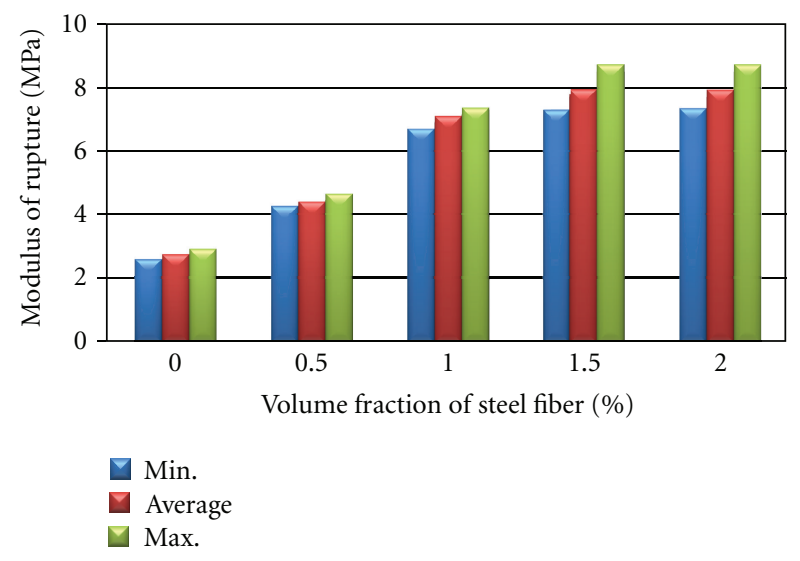

FIGURE 8: Effect of steel fiber addition on the modulus of rupture of HyFRLWC with $0.1 \%$ PPF and various volume fractions of SF.

but still achieves much better tensile strength compared to the reference mixture.

Experimental results which evaluated the effects of hybrid fiber addition on the flexural strength of hardened lightweight pumice breccia aggregate concrete can be observed in Figure 8. Hybrid fiber addition consequently leads to significant improvement on the modulus of rupture up to $187.46 \%$ when the concrete mix is added with the combination of $0.1 \%$ PPF and $1.5 \%$ SF. After the optimum volume fraction of fibers addition, the modulus of rupture tends to decrease but still obtains much better result compared to the reference concrete mixture.

Figure 9 shows load-deflection curves of all concrete variants to get more comprehensive results in the flexural behavior of HyFRLWC with pumice breccia aggregate. Based on the load-deflection curves, it can be observed that HyFRLWC with pumice breccia aggregate shows better post-peak behavior in resisting applied bending moment compared to the reference concrete. HyFRLWC variants exhibit more ductile behavior and higher residual strength. This characteristic can be obtained due to the effect of steel fiber on the energy absorbing mechanism by bridging action to distribute macro-cracks that are caused by applied external force, while polypropylene fiber shows its contribution to delay the formation of micro-cracks, improve the pullout strength of steel fiber, and avoid catastrophic breaking. Furthermore, it can be concluded that the presence of hybrid polypropylene-steel fiber addition in lightweight concrete with pumice breccia aggregate shows its contribution to improve post-peak behavior and avoid sudden tension failure in concrete section when it is utilized to resist bending moment.

\section{Conclusions}

Based on the tests results of the fresh and hardened properties of fiber reinforced lightweight pumice breccia aggregate concrete, the following conclusions can be drawn.

(1) In the fresh state of lightweight pumice breccia aggregate concrete, the addition of steel fibers consequently causes lower workability.

(2) The demoulded density of fiber-reinforced lightweight concrete tends to increase in accordance with the amount of steel fiber addition but generally can be classified as lightweight concrete based on most international standards of concrete structures.

(3) The compressive strength of lightweight concrete can be improved proportionally up to $22.44 \%$ when the hybrid polypropylene-steel fiber is added with the combination of $0.1 \%$ PPF and $1.0 \%$ SF then tends to decrease but still shows better performance compared to the reference concrete mixture.

(4) The modulus of elasticity also improved in accordance with the addition of hybrid fiber up to $24.71 \%$ when the concrete is added with the combination of $0.1 \%$ PPF and $0.5 \%$ SF then tends to decrease but is generally higher than the reference mixture.

(5) Higher splitting tensile strength of hardened fiberreinforced lightweight concrete specimens can be obtained up to $222.28 \%$ when the hybrid fiber is added with a combination of $0.1 \%$ PPF and $1.5 \%$ SF then decreases after the optimum value but still achieves much higher strength compared to the reference concrete mixture.

(6) The modulus of rupture of fiber-reinforced lightweight concrete specimens can be improved proportionally up to $187.46 \%$ when the hybrid polypropylene-steel fiber is added with the combination of $0.1 \% \mathrm{PPF}$ and $1.5 \%$ SF then decreases but still exhibits much better flexural performance compared to the reference concrete mixture. 


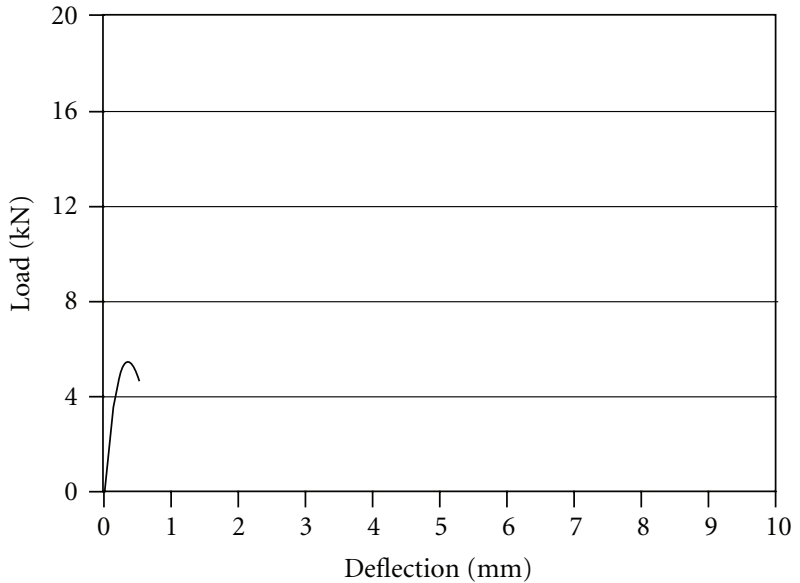

(a)

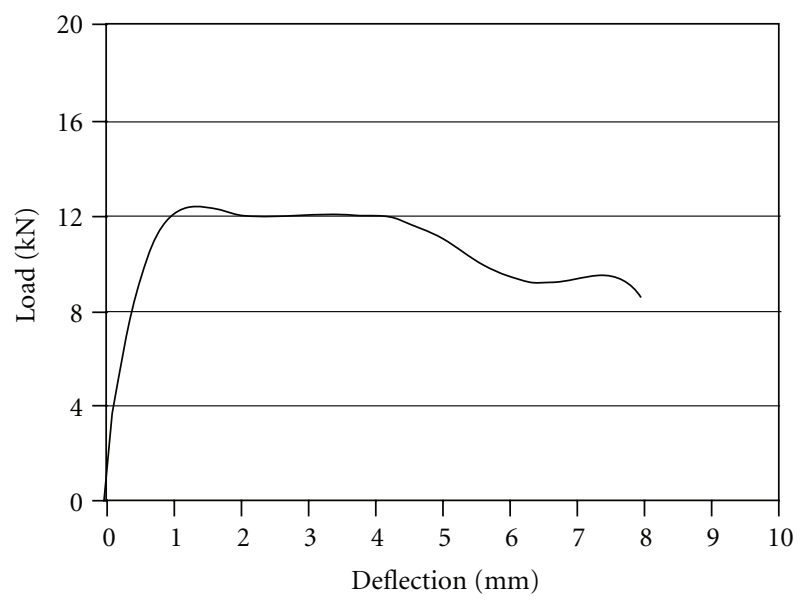

(c)

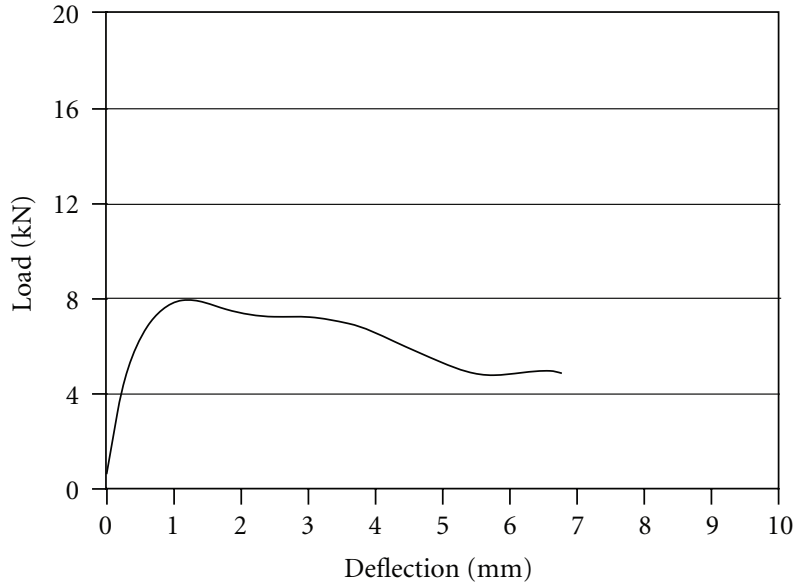

(b)

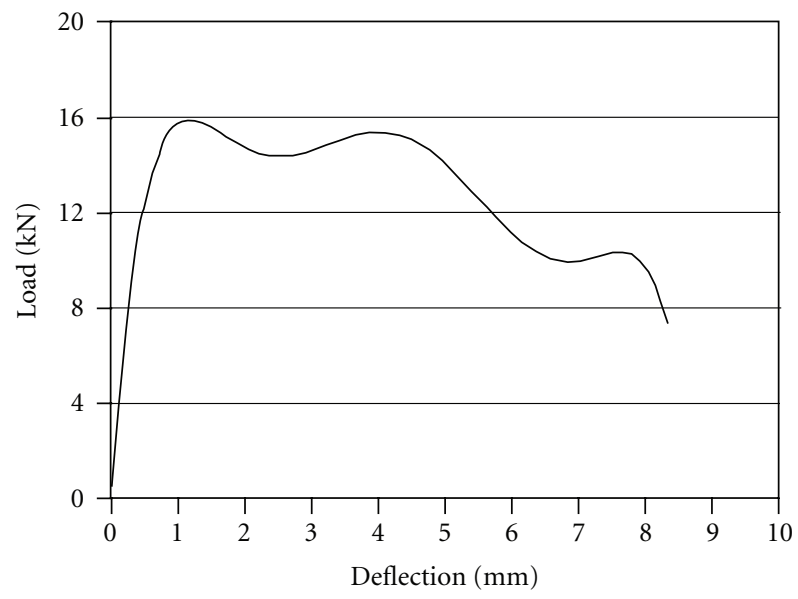

(d)

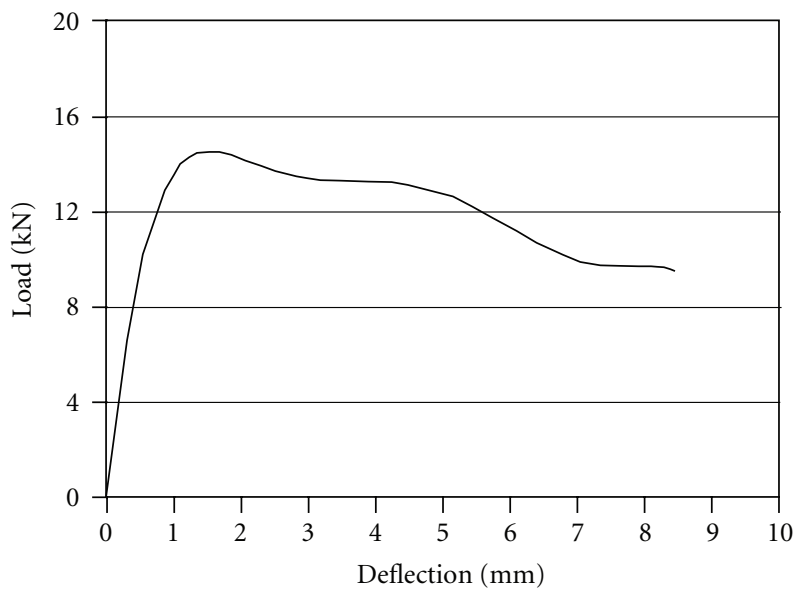

(e)

Figure 9: Load-Deflection Behavior of Center-Point Loaded Simply Supported Beams of HyFRLWC with Pumice Breccia Aggregate Added with $0.1 \%$ PPF and (a) $0.0 \%$ SF, (b) $0.5 \%$ SF, (c) $1.0 \%$ SF, (d) $1.5 \%$ SF and (e) $2.0 \%$ SF.

\section{Disclosure}

The paper has not been previously published, is not currently submitted for review to any other journal, and will not be submitted elsewhere before a decision is made by this journal.

\section{Acknowledgments}

The authors highly appreciate the financial support from Universitas Negeri Yogyakarta (Yogyakarta State University) and partial material support which is provided by PT Bekaert Indonesia. The support of the Building Material 
Laboratory staff at the Faculty of Engineering, Universitas Negeri Yogyakarta, and their assistance in conducting the experimental works are also gratefully acknowledged.

\section{References}

[1] EuroLightCon, Definitions and International Consensus Report, European Union-Brite EuRam III, 1998.

[2] National Standardization Body of Indonesia, SNI: 03-28472002: Design Procedure of Concrete Structures For Buildings, the National Standardization Body, Bandung, Indonesia, (In Indonesian).

[3] S. M. F. Green, N. J. Brooke, L. G. McSaveney, and J. M. Ingham, "Mixture design development and performance verification of structural lightweight pumice aggregate concrete," Journal of Materials in Civil Engineering, vol. 23, no. 8, pp. 1211-1219, 2011.

[4] N. Kabay and F. Akoz, "Effect of prewetting methods on some fresh and hardened properties of concrete with pumice aggregate," Cement \& Concrete Composites, vol. 34, no. 4, pp. 503-507, 2011.

[5] L. Xiaopeng, Structural lightweight with pumice aggregate [M.S. thesis], National University of Singapore, 2005.

[6] S. F. U. Ahmed, M. Maalej, and P. Paramasivam, "Flexural responses of hybrid steel-polyethylene fiber reinforced cement composites containing high volume fly ash," Construction and Building Materials, vol. 21, pp. 1088-1097, 2007.

[7] F. Altun, T. Haktanir, and K. Ari, "Effects of steel fiber addition on mechanical properties of concrete and RC beams," Construction and Building Materials, vol. 21, no. 3, pp. 654661, 2007.

[8] N. Banthia and N. Nandakumar, "Crack growth resistance of hybrid fiber reinforced cement composites," Cement and Concrete Composites, vol. 25, no. 1, pp. 3-9, 2003.

[9] A. Sivakumar and M. Santhanam, "Mechanical properties of high strength concrete reinforced with metallic and nonmetallic fibres," Cement and Concrete Composites, vol. 29, no. 8, pp. 603-608, 2007.

[10] National Standardization Body of Indonesia, SNI: 15-03022004: Pozzolan Portland Cement, the National Standardization Body, Bandung, Indonesia, 2004, (In Indonesian).

[11] J. Newman and B. S. Choo, Advanced Concrete Technology (Processes), Elsevier, Oxford, UK, 2003.

[12] M. Hassanpour, P. Shafigh, and H. Bin Mahmud, "Lightweight aggregate concrete fiber reinforcement-a review," Construction and Building Materials, vol. 37, pp. 452-461, 2012.

[13] A. Sadrmomtazi, M. A. Mirgozar Langeroudi, A. Fasihi, and A. K. Haghi, "An investigation on effect of using PP fibers and different cementitious materials on mechanical properties of EPS concrete," in Proceeding of 3rd International Conference on Concrete \& Development, pp. 1035-1044, 2009.

[14] ASTM C-143, C-469, C-496, and C-293, "Annual Book of ASTM Standard, Volume 04. 02: Concrete and Aggregates,” ASTM International, West Conshohocken, Pa, USA, http://www.astm.org/.

[15] British Standard, Concrete-Complementary British Standard to BS EN 206-1-Part 1: Method of Specifying and Guidance for the Specifier, BS, 8500-1:2006, BSI, 2006. 

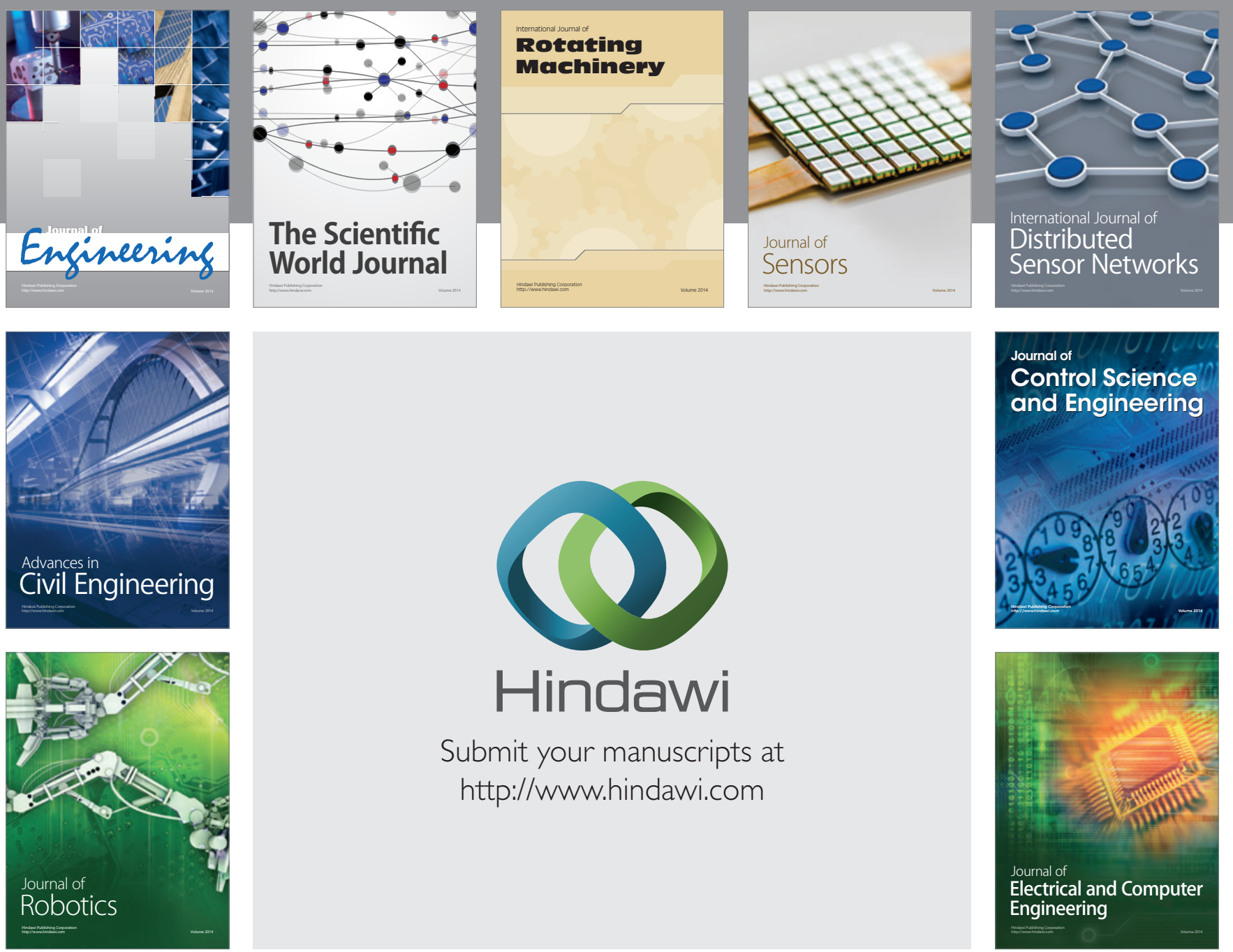

Submit your manuscripts at

http://www.hindawi.com
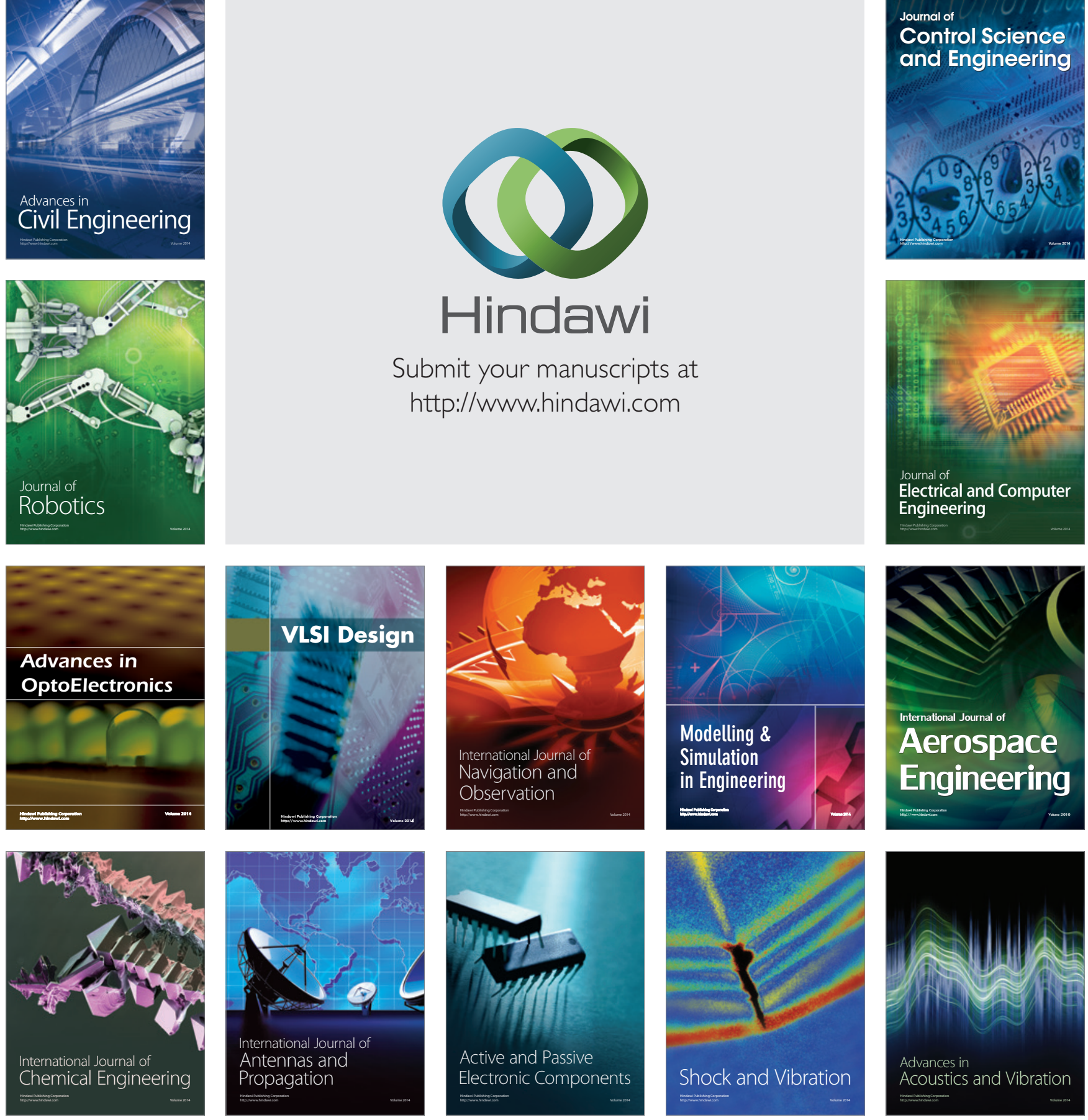